\title{
In Memory of Academician Nikolai Grigorievich Khrushchev (1932-2009)
}

\author{
DOI: $10.1134 / \mathrm{S} 1062359009040189$
}

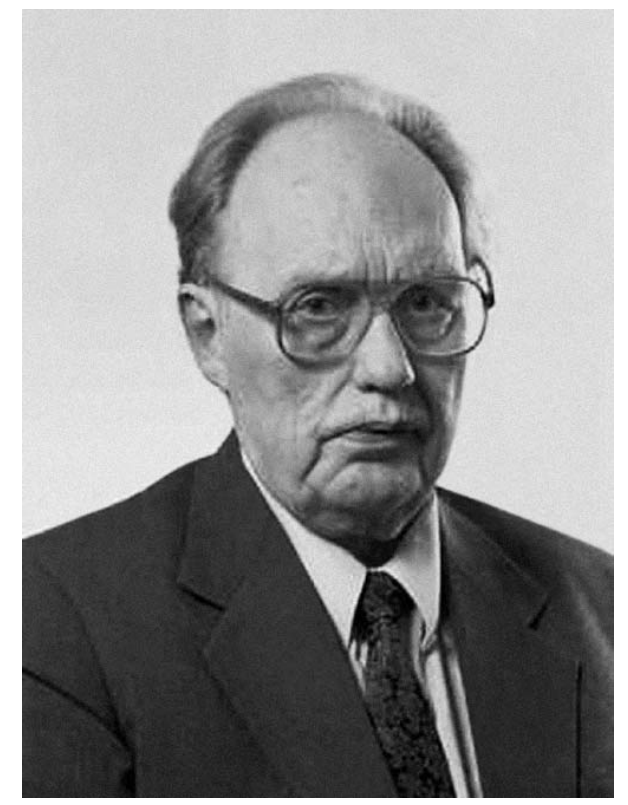

On April 2, 2009, Academician Nikolai Grigorievich Khrushchev passed away after a long and serious illness.

Khrushchev was born on January 23, 1932, in Leningrad. In 1956 he graduated from Moscow's 2nd Medical Institute. He defended his candidate's dissertation in 1959. Since 1963 his fate was inextricably bound to the Kol'tsov Institute of Developmental Biology, Russian Academy of Sciences (RAS), in which he traveled the path from senior researcher to director. Heading this institute from 1989 to 2004, Khrushchev did a great deal to support its authority and prestige in years that were difficult for Russian science.

Khrushchev was one of the initiators of stem cell research in Russia; he was a leading specialist in this field of developmental biology and was the founder of the scientific school of the mechanisms of proliferation and differentiation of embryonal and tissue-specific stem cells in onto- and phylogenesis under pathology and extreme effects. Under his direction, the mechanisms of the regulatory role of hematopoietic stroma in the differentiation of hematopoietic cells were revealed. In recent years he began studies on researching embryonal stem cells, on how spaceflight factors influence the hematopoietic system, etc. His research results were generalized in 300 papers and the monographs "Functional Cytochemistry of Loose Connective Tissue" (1960) and "Histogenesis of Loose Connective Tissue" (1975).
In 1990 Khrushchev was elected a full member of the Academy. For his scientific achievements he was honored with the RAS I.I. Menchikov award, an Outstanding Scientists of the RAS award, and the Order of People's Friendship.

Khrushchev spent much energy on training young scientists. He was a professor of the chair of cellular biology and histology of Moscow State University's biology faculty, where he earned the rank of honored professor.

Khrushchev carried out a great deal of scientific-organizational activity. He was a member of the RAS Division of General Biology, and from 1998 to 2002, he was its academician-secretary. In addition he headed the RAS Scientific Council on Developmental Biology, as well as the awards commission for the A.O. Kovalevskii and I.I. Shmal'gauzen prizes; he was also a member of the editorial boards of Doklady Rossiiskoi Akademii Nauk and Ontogenez (Developmental Biology).

Since 1998 Khrushchev had been the editor-in-chief of Izvestiya RAN. Seriya Biologiya (Biology Bulletin). He devoted much attention to the journal, the pages of which were graced by materials on nearly every direction of modern biology.

The departure of Nikolai Grigorievich Khrushchev from this life is a profound loss for Russian science. His memory will shine on. 